\title{
Studies on Independent College Application-oriented Talents Training Mode under New Normal
}

\author{
$\mathrm{Han} \mathrm{He}^{1, \mathrm{a}}$, Jingying $\mathrm{YaO}^{1, \mathrm{~b}}$ and Jun $\mathrm{Li}^{2,3, \mathrm{c} *}$ \\ ${ }^{1}$ Rongzhi College of Chongqing Technology and Business University, Chongqing 400067, China \\ ${ }^{2}$ School of Biological and Chemical Engineering, Chongqing University of Education, Chongqing \\ 400067, China \\ ${ }^{3}$ Chongqing Collaborative Innovation Center for Functional Food, Chongqing University of \\ Education, Chongqing 400067, China \\ agene771771@hotmail.com, byjy188953@hotmail.com, c247491362@qq.com \\ *The corresponding author
}

\begin{abstract}
Keywords: Independent college; Applicable talents training mode; New normal
\end{abstract}
\begin{abstract}
As the economic growth steps into a new normal, society has greatly changed its demand for talents----lack of high-quality and skilled professionals has become bottleneck problem that impedes our economic growth and applicable talents with high quality are imminently demanded. However, traditional talent training mode by independent college no longer adapts to economic structure adjustment and innovation-driven development. Independent college, meeting the market demand as well as integrating its own characteristics, should target at training application-oriented talents who are society adaptable. This essay analyses the status and problems of talent training mode by independent college under new normal and proposes corresponding solutions and advices.
\end{abstract}

\section{Introduction}

The economic development in China has entered an new normal - new jobs gradually diminishes during the slowdown as China transferred from rapid economic growth to medium-high economic growth; on the other hand, with the difficult structural adjustments, there is an enormous increase in structural unemployment. Economic structural adjustments, rapid industrial upgrading and social culture construction contribute to a great change in talents demand. Export, investment and consumption, which are so called "three carriages" that drive economic growth, have been replaced by institutional reform, structure optimization and factor upgrading. Government possesses less social resources and attenuate its dominance in market resources allocation. As a result, absorbing and accommodating jobs dominated by government suffered a reduction and applied high-quality talents who accommodate to society are constantly demanded. However, with economic transition, poor general education and low public scientific literacy, a batch of labor that are not able to adjust with social demand are squeezed out. Consequentially, lack of high-quality and skilled professionals have become the bottleneck problem that impedes China's economic growth.

Independent college is a vital component that constitutes higher education system. According to the statistic, there have been 266 independent colleges by 2016. Traditional talents training mode cannot adapt to economic structure adjustment and innovation-driven development. Personnels trained by independent colleges hold weak theoretical basis, incapable practical skills and low employment rate, demonstrating homogenization compared with personnel from public universities. Independent college cannot compare to public universities in school history, culture reputation, school conditions and faculty quality. In this case, independent college should aim at training distinctive talents, make best use of advantages and bypass disadvantages, meet market demand and target at training society-adaptable talents and create its own styles with its characteristics. 


\section{Talent Training Mode Status and Existing Problems of Independent College}

Obsolete School Running Ideas. Quite a few administrative authorities' school running ideas remain traditional and outmoded. Most administrators as such, are retired administrators from parent school or other public universities. Obsolete ideas from administrative team blurred nature, characteristics, mode and direction of development planning, which fades school running's vitality, creativity, crisis awareness and sense of urgency, courage and motivation to reform.

A Common Phenomenon--Curriculum Setting "Clone". Most independent colleges just transplant full-blown subjects from previous public universities. It is demonstrably pointed that: Major setting in independent college should locally and regionally meet social and economic demand. No effort shall be spared to create conditions to develop majors that are in badly social and human resource need ([2003], NO.8, by MOE of China) It is common to model subjects setting in independent college. This fades its distinguishing feature and impact its indie development and motivation.

Confusing and Impractical Major Setting. Independent college aspires to comprehension and profession in major setting. To attract students, major sets from economy to management, art to science and engineering to law, covering all-round subjects that seem a high-end future. Meanwhile, inferiority education due to facility deficiency and insufficient faculty brings about predicament in graduate employment. Majors as such have to be pulled the plug on when facing enrollment dilemma.

Inappropriate Faculty Structure. Faculty in independent college still relies on its parent public university, which mainly consists of four parts: part-time teacher from parent school, rehired teacher who has retired from parent school, dual-qualification teacher from the external and full-time teacher trained by independent college. It is a common problem for most independent college that the majority faculty are from parent school, especially at the beginning of the school establishment.

Talents Training Dismatches Social Demand. Talent training requires scientific investigation, proper training plan setting and insightful career vision, without which, it is inevitable to run counter to market demand. Moreover, improper talent training orientation results in low target achievement. Talents training dismatches social demand.

\section{Application-Oriented Talent Training Methods for Independent Institution}

Target at Application-Oriented School in Terms of Social Demand. It is explicitly stated that: independent college should focus on serving local economic and social development, promoting work-integrated education with alumni enterprise, training applicable and practical talents, improving graduates start-up ability and employment and comprehensively enhancing its regional economic and social development and innovation capability. ([2003], NO.8, by MOE of China). Concerning the facilities and software condition, independent college should have a various development strategy and seek distinction with public universities. Based on local economy, industrial environment and market demand, independent college should target at training practical and application-oriented talents with innovation and distinction, standing out from the fierce competition.

Establish Characteristic Discipline Based Parent School Resources. Regarding to discipline setting, independent college may make use of full-blown disciplines in parent school rather than transplant them. By making effective use of parent school resources, independent college could adjust discipline setting in three aspects: 1. Market need and developing trend. Based on local industrial policy, independent college should realize its distinction with parent school and constantly acquire talent market information. In this way independent college can master market demand status and developing trend. 2. Discipline adjustment. It is essential to do feasibility analysis which includes facilities, faculty quality, financial assessment and so on. 3. Distinguishing discipline establishment. Independent college should take imbalanced developing strategy that strengthen promising discipline with abundant resources. There is no need and, precisely, no 
strength to cover all round development.

Enhance Teaching Staff in All Aspects. Due to its exceptional feature and conditional limitation, independent college is in an inferior position when recruiting talents. Teaching staff are vital part of the education system and the implementer who conduct talent training. Therefore, faculty improvement should be taken as the focus in school development, which includes: 1 . Enlarge professionals recruitment. Independent college should enlarge high-level talents recruitment, who are the guarantee of qualified and authentic education. Meanwhile, practical experience plays an equal role compared with educational background. 2. Enhance in-service faulty qualification, especially dual-qualification teachers. As for fresh youthful teachers, tutors from the industry can be assigned to give practical guidance. Moreover, occupying teachers in independent college are encouraged to acquire professional certificates and take secondment duty in corresponding industry as long as no negative impact would be laid on normal teaching activities. 3 . Enlarge external dual-qualification teacher recruitment. Both theoretical and practical teachers, who have rich practical experience and master newest applied skills, are highly demanded in teaching activities. 4. Adjust faculty component. Independent college should primarily rely on its own teaching staff and be supplemented by external teachers from parent school and external dual-qualification teachers. Then, age distribution should be taken into consideration. Though the elder teacher takes an advantage in teaching experience, young teacher more tends to accept new ideas with innovation and practical passion. Therefore, it is essential to appropriately manage faculty component, theoretically and practically.

Combine Practical Training with Social Development Trend. Practical teaching plays an important role in training applicable talents. Most independent college have established practice teaching system and laboratory. However, they are limited to form that has low educational quality. To solve these problems, it is suggested to: 1. attach high importance to practice training, which means both teachers and students ought to realize the importance of practical training and teachers are forged to promote theory with practice in educational activities; 2 . ensure the quality of practical training and produce effective and market-oriented training. School should try its best efforts to provide demanding resources for practical training and constantly reform teaching activity, methodology and medium in terms of teaching need. 3. promote practice-oriented textbook . Textbooks that are specialized for training practical talents are below average level. Independent college targets at training distinct talents compared with public school. So, normal textbooks compiled by public school do not work out in talent training practice. As a result, independent college need to organize professionals to compile and design practice-oriented textbooks targeting at training practical talents ,combining theory and practice. 4. strengthen laboratory and practice platform construction. Independent college should make best use of parent school resources and centralize resources to construct laboratory and practice platform according to key and distinctive discipline development and talent training targets. 5. rationally use industrial resources and establish industrial cooperation. Work-integrated education, which ensures practical teaching reform, may involve students in the enterprise operation and management, meanwhile, improve industrial elitists' theoretical skill and, likewise involve tertiary teachers in product research, design and production. Undoubtedly, work-integrated education creates mutual benefit and common development for both sides.

\section{Conclusion}

In brief, under the instruction of major national strategies, including innovation-driven development, made in china 2025, internet plus, mass entrepreneurship and innovation, and the belt and the road initiatives, independent college should adjust to new normal of economic development and serve innovation-driven development, train applied-oriented talents in terms of social need with acting point and break through, serve regional economic and social development, improve enterprise technology and create value for learners. 


\section{References}

[1] W. Yan, N.H. Feng, T.T. Li, On Application oriented undergraduate talent training model based on industry university cooperative education - a micro case study from tourism management specialty, J. Educ. Teach. Res. 25 (2011) 76-80.

[2] T.L. Gu, X.X. Jing, Q. Guo, Y.X. Wei, A research on the training mode reform of college engineering practical talents, J. China High. Educ. Res. 1 (2012)107-110.

[3] D.N. Pan, Research on school-enterprise cooperation in tourism education in undergraduate institutions, J. Univ. Educ. 11 (2012)8-11.

[4] Q.Z. Luo, Y.Y. Xu, Exploration on school - running features of local universities - take foshan university as an example, J. High. Educ. Forum. 5 (2009) 8-11

[5] F.F. Weng, Z.J. Liu, NCIST's schooling orientation, characteristics and internationalization strategy, J. North China Inst. Sci. Technol. 7 (2012) 118-121

[6] C.F. Ge, A Study of the construction on specialty cluster of thenewly-established application oriented universities, J. High. Vocat. Educ. - J. Tianjin Vocat. Inst. 4 (2013) 48-51

[7] G.H. J, W.X. H, Characteristic research on the independent colleges' application-oriented personnel training programs, J. Educ. Sci. Hunan Nor. Univ. 9 (2009) 94-96

[8] W.Y. Chen, Study on optimizing training program for application- oriented talents in independent colleges, J. Huazhong Agri Univ. 1 (2011) 136-139

[9] J.B. Yuan, Innovation and practice of the training mode of applied talents in independent colleges, J. Res. High. Educ. Engine. 2 (2011) 118-123

[10]P.Y. Duan, Analysis of research-oriented teaching and learning modes for cultivation of application-oriented innovative talents, J. Shangdong Jianzhu Univ. 8 (2012) 440-450.

[11]Y. Luo, On the innovative application talents training mode for the major of environment art design, J. Jiangsu Jianzhu Inst. 9 (2015) 58-61.

[12]J.H. Liu, A probe into innovative application-oriented talents training model of new undergraduate colleges, J. Xinyu Univ. 4 (2012) 50-51.

[13]C. Jiang, Exploration and analysis of teaching reform on advanced mathematics under research-based teaching mode, J. Shenyang Nor. Univ. 10 (2012) 562-565.

[14]X.Q. Li, Analysis on the Cultivation of Application-Oriented Talents Majoring in English in Independent Colleges, J. Sci. Educ. Art. Coll. 6 (2013) 83-84

[15]H. Xie, Research on Training Application Undergraduate Talents, J. Chongqing Three Gorges Univ. 3 (2009) 122-124 